Agrisaintifika

Jurnal Ilmu-Ilmu Pertanian

Vol. 2, No. 1, 2018

\title{
Proteksi Tepung Ikan Menggunakan Asap Cair dari Tempurung Kelapa Terhadap pH dan $\mathrm{NH}_{3}$
}

\author{
Catur Suci Purwati ${ }^{1}$ \\ ${ }^{1}$ Jurusan Peternakan, Fakultas Pertanian, Universitas Veteran Bangun Nusantara, Sukoharjo \\ 57521 Telp. +6285647157818 E-mail: catursuci88@gmail.com
}

\begin{abstract}
ABSTRAK
Tujuan dari penelitian ini adalah mengetahui Pengaruh Proteksi Tepung Ikan Menggunakan Asap Cair dari Tempurung Kelapa terhadap Fermentabilitas In Vitro dilihat dari $\mathrm{NH}_{3}$ dan $\mathrm{pH}$ dan mengetahui konsentrasi asap cair yang dapat digunakan pada proteksi bahan pakan tinggi protein. Penelitian ini dilakukan dengan menggunakan Rancangan Acak Lengkap dengan tiga perlakuan dan 2 ulangan. Perlakuan sebagai berikut: : $\mathrm{P} 0=$ Tepung ikan tanpa perlakuan, $\mathrm{P} 1=$ Tepung ikan + Asap cair dari tempurung kelapa konsentrasi $10 \%, \mathrm{P} 2=$ Tepung ikan + Asap cair dari tempurung kelapa konsentrasi $20 \%$, $\mathrm{P} 3=$ Tepung ikan + Asap cair dari tempurung kelapa konsentrasi $30 \%$. Peubah yang diamati $\mathrm{NH}_{3}$ dan $\mathrm{pH}$. Masing-masing perlakuan ditambahkan asap cair sebanyak $5 \%$. Tepung ikan diproteksi dengan asap cair dari tempurung kelapa caranya dengan menyemprotkan asap cair tersebut ke bahan tersebut kemudian didiamkan semalam. Hasil rerata nilai kadar $\mathrm{NH}_{3}$ pada penelitian ini antara $11-23 \mathrm{mg} / 100 \mathrm{gram}$. Rerata $\mathrm{pH}$ $\mathrm{P} 0$ dan $\mathrm{P} 1$ yang dihasilkan adalah $5,75 \pm 0,01$ dan $5,51 \pm 0,01$ sedangkan $\mathrm{P} 2$ dan $\mathrm{P} 3$ masing-masing $5,32 \pm 0,01$ dan $5,20 \pm 0,01$. Kadar $\mathrm{NH}_{3}$ dan $\mathrm{pH}$ yang ideal sesuai dengan kondisi didalam rumen adalah proteksi tepung ikan mengunakan asap cair dengan konsentrasi $0 \%$ dan $10 \%$
\end{abstract}

Kata kunci : Asap cair, $\mathrm{NH}_{3}, \mathrm{pH}$, proteksi, tepung ikan

Fish Flour Protection Used Liquid Smoke from Shell of Coconut to $\mathrm{NH}_{3}$ and $\mathrm{pH}$.

\section{ABSTRACT}

This research aims to know the Influence of fish flour protection using liquid smoke from coconut shell toward fermentability of In Vitro seen from $\mathrm{NH}_{3}$ and $\mathrm{pH}$. It is also to know the concentration of liquid smoke which can be used on protecting high protein feedstuff. This research was carried out using Random Device Complete involving three treatments and 2 repetitions. The treatments are $P O=$ Fish flour without treatment, P1 = Fish flour + Liquid Smoke from coconut shell in 10\%,concentration, P2 = Fish meal + Liquid Smoke from coconut shell in concentration $20 \%$, and P3 = Fish meal + Liquid Smoke from coconut shell in concentration $30 \%$. The variables were $\mathrm{NH} 3$ and $\mathrm{pH}$. Each treatment was added liquid smoke as many as 5 $\%$ from the total of fish flour on treatment. Fish flour was protected by liquid smoke from coconut shell by spraying the liquid smoke to the materials. It was then hushed for one night. The average result of $\mathrm{NH}_{3}$ content in this research was between $11-23 \mathrm{mg} / 100 \mathrm{gram}$. Average $\mathrm{pH}$ of $P 0$ and $P 1$ resulted in 5,75 0,01

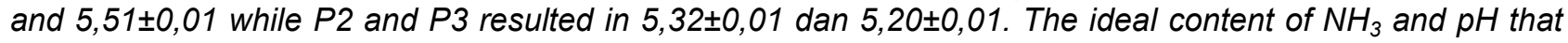
were appropriate with the situation in the rumen was fish flour protected using liquid smoke in $0 \%$ and $10 \%$ concentration.

Keyword : fish meal, liquid smoke, $\mathrm{NH}_{3}, \mathrm{pH}$, protection

\section{PENDAHULUAN}

Tepung ikan lokal yang bersumber dari sisa industri ikan kalengan atau limbah tangkapan nelayan dan hanya dijemur dengan panas matahari mempunyai kandungan protein kasar hanya 51-55\%. Selain sebagai sumber protein dengan asam amino yang baik, tepung ikan juga merupakan sumber mineral dan vitamin. Dengan kandungan gizi yang sangat baik ini 
maka tepung ikan dipasaran harganya relatif mahal.

Bahan pakan yang berkualitas baik yaitu kandungan protein yang tinggi seperti tepung ikan diberikan perlakuan agar tidak terdegradasi oleh mikroba rumen dengan cara diproteksi untuk meningkatkan efisiensi pencernaan. Soebarinoto et al. (1991) menyatakan bahwa perlindungan protein selama proses fermentasi berlangsung dapat dilakukan dengan penambahan bahan kimia misalnya formaldehid. Perlindungan protein di dalam rumen dengan menggunakan formaldehid menyebabkan terbentuknya ikatan methylen dengan protein yang menyelubungi lapisan luar matrik protein (Mc Allister et al., 1989 cit Anggraeny dan Krishna, 2005). Namun penggunaan formaldehid pada bahan pakan dibatasi, sehingga untuk proteksi bahan pakan yang berkualitas baik seperti tepung ikan perlu digantikan dengan bahan alternatif yang tidak berbahaya, salah satunya bisa mengunakan asap cair. Asap cair merupakan bahan kimia hasil destilasi asap hasil pembakaran. Asap cair mampu menjadii desinfektan sehingga bahan makanan dapat bertahan lama tanpa membahayakan konsumen (Amritama, 2007).

Penggunaan asap cair dari tempurung kelapa untuk pengawetan bahan makanan seperti mie basah, tahu, daging ayam, bakso, daging sapi segar, daging sapi asap, serta ikan untuk meningkatkan keamanan pangan dan lingkungan khususnya dengan menggunakan asap cair akan semakin besar peranannya dalam penyediaan dan pemenuhan protein baik hewani dan nabati, dan mencegah penggunaan pengawet berbahaya seperti formalin. Khususnya untuk ternak ruminansia penambahan asap cair pada bahan pakan tinggi protein seperti tepung ikan diharapkan mampu melindungi bahan pakan agar tidak di degradasi oleh mikrobia rumen selama proses fermentasi, serta dapat digunakan sebagai alternatif bahan yang dapat menggantikan peranan formaldehid dalam proses proteksi pakan sehingga mampu mengurangi proses degradasi oleh mikrobia rumen, yang dapat dilihat dari kadar $\mathrm{NH}_{3}$ dan $\mathrm{pH}$ melalui uji fermentabilitas in vitro.

\section{BAHAN DAN METODE}

\subsection{Tempat Penelitian}

Penelitian Pengaruh Proteksi Tepung Ikan Menggunakan Asap Cair dari Tempurung Kelapa terhadap $\mathrm{pH}$ dan $\mathrm{NH}_{3}$ telah dilaksanakan di Laboratorium Program Studi Peternakan Fakultas Pertanian Univet Bantara Sukoharjo dan Laboratorium Bagian Nutrisi dan Makanan Ternak Fakultas Peternakan UGM. Waktu penelitian selama 3 bulan. Bahan tepung ikan didapatkan dari daerah Boyolali, Jawa Tengah, sedangkan asap cair dari tempurung kelapa didapatkan di Brajan RT 02 Wonokromo, Pleret, Bantul, Yogyakarta.

\subsection{Metode Penelitian}

Penelitian ini dilakukan dengan menggunakan Rancangan Acak Lengkap dengan empat perlakuan dan 2 ulangan. Perlakuan sebagai berikut :

P0 = Tepung ikan tanpa perlakuan (asap cair dari tempurung kelapa konsentrasi $0 \%$ )

$\mathrm{P} 1=$ Tepung ikan + Asap cair dari tempurung kelapa konsentrasi $10 \%$

P2 = Tepung ikan + Asap cair dari tempurung kelapa konsentrasi $20 \%$

P3 = Tepung ikan + Asap cair dari tempurung kelapa konsentrasi $30 \%$

Penambahan asap cair pada masingmasing perlakuan adalah sebanyak $5 \%$ dari tepung ikan. Tepung ikan diproteksi dengan asap cair dari tempurung kelapa dengan menyemprotkan asap cair ke bahan tersebut kemudian didiamkan semalam. Peubah yang diamati fementabilitas $\mathrm{NH}_{3}$ dan $\mathrm{pH}$.

Data penelitian dianalisis menggunakan analisis variansi berdasarkan Rancangan Acak Lengkap. Apabila hasil analisis data 
menunjukkan ada pengaruh perlakuan maka dilanjutkan dengan uji beda Duncan Multiple Range Test

Model Matematika yang dipergunakan adalah:

Keterangan :

$$
Y i j=\mu+\pi i+\varepsilon i j
$$

Yij = Nilai pengamatan perlakuan ke-i dan ulangan ke-j

$\mu=$ Rataan nilai dari seluruh perlakuan

$\pi \mathrm{I}=$ Pengaruh perlakuan ke-i

$\varepsilon i j=$ Pengaruh galat perlakuan ke-i dan ulangan ke-j

(Yitnosumarto, 1993).

\section{Penentuan fermentabilitas in vitro (Tilley} and Terry, 1967)

Satu gram tepung ikan perlakuan dimasukkan ke dalam tabung fermentor polyethylen, ditambahkan $10 \mathrm{ml}$ cairan rumen dan $40 \mathrm{ml}$ larutan Mc Douglass pada suhu $39^{\circ} \mathrm{C}$. Ditutup dengan karet berventilasi dan diinkubasi selama 3 jam di dalam waterbath. Selanjutnya ke dalam setiap tabung ditetesi $\mathrm{Hg}_{2} \mathrm{Cl}$ untuk membunuh mikrobia. Tabung disetrifus pada kecepatan 10.000 rpm selama

\section{HASIL DAN PEMBAHASAN}

\section{A. Kadar $\mathrm{NH}_{3}$}

Kadar ammonia di dalam rumen sangat dipengaruhi oleh kandungan protein pakan, $\mathrm{pH}$ rumen, dan kelarutan protein bahan pakan. Ternak ruminansia diberikan pakan jerami padi dengan kandungan protein rendah $(5,12 \%)$ memiliki konsentrasi ammonia sangat rendah yaitu 22,9\%. (Mahesti, 2009). Mikroba dapat bekerja dengan optimal untuk merombak asam amino yang selanjutnya digunakan untuk
20 menit bagian supernatan dianalisis kadar $\mathrm{NH}_{3}$ dan $\mathrm{pH}$.

\section{Analisis pH dan Konsentrasi $\mathrm{NH}_{3}$}

Pengukuran $\mathrm{pH}$ mengunakan $\mathrm{pH}$ meter digital. Pengukuran $\mathrm{NH}_{3}$ menggunakan metode mikrodifusi Conway (General Laboratory Procedures, 1966). Cawan Conway yang dimodifikasi dipersiapkan untuk analisis produksi amoania cairan rumen. Alat ini terpisah tiga sekat namun dalam satu ruang yang sama. Satu $\mathrm{ml}$ supernatan ditambahkan dengan $\mathrm{Na}_{2} \mathrm{CO}_{3}$ jenuh dalam satu sekat yang lain dimasukan asam borat berindikator untuk menangkap amonia yang terbentuk dari reaksi sampel cairan rumen dan $\mathrm{Na}_{2} \mathrm{CO}_{3}$. segera sampel dimasukan, Cawan Conway segera ditutup dan biarkan selama 24 jam. Selanjutnya dilakukan dengan menggunakan $\mathrm{HCl}$ dan 0,01 N.

Perhitungan Konsentrasi N-Amonia

$$
\begin{gathered}
\text { Konsentrasi N-Amonia }=(\mathrm{ml} \mathrm{HCl} \\
x \mathrm{~N} \mathrm{HCl} \times 1000) \mathrm{mM}
\end{gathered}
$$

menyusun protein tubuhnya. Amoniak juga merupakan nitrogen yang paling banyak dibutuhkan mikroorganisme rumen yang bersama dengan kerangka karbon dari sumber energi akan disintesa menjadi protein mikroba. Hungate, (1966), menjelaskan bahwa mikroorganisme sangat penting untuk mengatur kecepatan tumbuh dan efisiensi penggunaan makanan bagi ruminansia dan nutrisi mikroorganisme ini sangat penting untuk induk semang. Pada penelitian ini bahan pakan yang digunakan adalah tepung ikan kandungan proteinnya 40-55\%. 
Purwati. 2018

Tabel 1 Rerata kadar $\mathrm{NH}_{3}$ Proteksi Tepung Ikan Menggunakan Asap Cair Dari Tempurung Kelapa

\begin{tabular}{c|c}
\hline \hline Perlakuan & $\begin{array}{c}\mathrm{Kadar}_{\mathrm{NH}} \\
(\mathrm{mg} / 100 \text { gram })\end{array}$ \\
\hline P0 & $11,34 \pm 0,03^{(\mathrm{a})}$ \\
\hline P1 & $14,73 \pm 0,03^{(\mathrm{b})}$ \\
\hline P3 & $17,52 \pm 0,01^{(\mathrm{c})}$ \\
\hline \hline
\end{tabular}

Keterangan : Superscript yang berbeda menyatakan ada perbedaan signifikan $(P>0,05)$

Analisis variansi menunjukkan bahwa penggunakan asap cari dari tempurung kelapa pada proteksi tepung ikan berpengaruh signifikan $(P>0,05)$ terhadap kadar $\mathrm{NH}_{3}$. Rerata nilai kadar $\mathrm{NH}_{3}$ pada penelitian ini antara $11-23 \mathrm{mg} / 100$ gram. Penelitian sebelumnya yang pernah dilakukan dengan proteksi minyak ikan lemuru, minyak kelapa sawit, dan bungkil sawit terhadap $\mathrm{pH}$ dan $\mathrm{NH}_{3}$ dihasilkan konsentrasi amonia berkisar antara $9-12$ $\mathrm{mg} / 100 \mathrm{ml}$ (Purwati, 2010). Rerata Kadar $\mathrm{NH}_{3}$ tertinggi pada perlakuan 3 adalah 23,60

\section{B. Pengukuran pH}

Nilai $\mathrm{pH}$ dikatakan ideal apabila berada pada kisaran 6,5 sampai 7,0 . Nilai $\mathrm{pH}$ pada kisaran 6,5-7,0 mempertahankan proses mg/100 gram, nilai $\mathrm{NH}_{3}$ tersebut tidak berbeda jauh dengan pendapat pendapat Mehrez et al., (1977) cit Erwanto (1995) konsentrasi amonia yang lebih tinggi diperlukan untuk memaksimumkan laju fermentasi yaitu sebesar $23.5 \mathrm{mg} \%$ atau setara dengan $16.78 \mathrm{mM}$. Pada P0, P1, dan P3 rerata $\mathrm{NH}_{3}$ berturut-turut 11,34; 14,73: dan 17,52 dijelaskan oleh Satter dan Slyter (1974) cit Erwanto (1995) apabila kadar amonia medium kurang dari $3.57 \mathrm{mM}$ pertumbuhan mikrobia akan terhambat.

fermentasi dalam rumen tetap berjalan. Lebih lanjut Indrayanto (2013) menjelaskan bahwa produksi gas yang tinggi sejalan dengan kecernaan yang tinggi dan nilai $\mathrm{pH}$ yang lebih rendah.

Tabel 2 Rerata Pengukuran Proteksi Tepung Ikan Menggunakan Asap Cair Dari Tempurung Kelapa

\begin{tabular}{c|c}
\hline \hline Perlakuan & $\mathrm{pH}$ \\
\hline P0 & $5,75 \pm 0,01^{(\mathrm{a})}$ \\
\hline P1 & $5,51 \pm 0,01^{(\mathrm{b})}$ \\
\hline P2 & $5,32 \pm 0,01^{(\mathrm{c})}$ \\
\hline P3 & $5,20 \pm 0,01^{(\mathrm{d})}$ \\
\hline \hline
\end{tabular}

Keterangan : Superscript yang berbeda menyatakan ada perbedaan signifikan $(P>0,05)$

Analisis variansi menunjukkan bahwa penggunakan asap cari dari tempurung kelapa pada proteksi tepung ikan berpengaruh signifikan $(P>0,05)$ terhadap
$\mathrm{pH}$. Pada penelitian ini untuk $\mathrm{PO}$ dan $\mathrm{P} 1 \mathrm{pH}$ yang dihasilkan adalah 5,75 dan 5,51 sehingga dapat dikatakan kondisi kehidupan mikroorganisme masih dalam keadaan 
normal, sesuai dengan pendapat (Kamal, 1994) pada keadaan normal $\mathrm{pH}$ isi rumen dipertahankan antara 5,5-6,5. Sedangkan pada $\mathrm{P} 2$ dan $\mathrm{P} 3 \mathrm{pH}$ yang dihasilkan $5,32 \pm 0,16$ dan $5,20 \pm 0,01$ lebih rendah dari $\mathrm{pH}$ keadaan normal isi rumen yaitu 5,5 hal ini disebabkan karena pada P2 dan P3 konsentrasi asap cair yang dignakan lebih dari $15 \%$. Saliva bagi ruminansia mempunyai fungsi yang penting yaitu untuk menjaga $\mathrm{pH}$ isi rumen, sebab asam yang terjadi selama proses fermentasi akan dapat menurunkan $\mathrm{pH}$ cairan rumen sampai menjadi $2.5-3$. Penelitian lain mengenai nilai produksi gas, konsentrasi amonia dan $\mathrm{pH}$ ransum berbahan jerami padi, daun gamal dan UMML $\mathrm{pH}$ yang dihasilkan berkisar yaitu 6,72- 6,84 (Gusasi, 2014).

\section{SIMPULAN}

Hasil rerata nilai kadar $\mathrm{NH}_{3}$ antara 11 $23 \mathrm{mg} / 100$ gram. Rerata $\mathrm{pH}$ perlakuan proteksi tepung ikan mengunakan asap cair dengan konsentrasi $0 \%$ dan $10 \%$ yang dihasilkan adalah 5,75 dan 5,51 sedangkan konsentrasi $20 \%$ dan $30 \%$ masing-masing 5,32 dan 5,20. Kadar $\mathrm{NH}_{3}$ dan $\mathrm{pH}$ yang ideal sesuai dengan kondisi didalam rumen adalah proteksi tepung ikan mengunakan asap cair dengan konsentrasi $0 \%$ dan $10 \%$.

\section{DAFTAR PUSTAKA}

Anggraeny, Y.U., dan K.N. Hudia. 2005. Efektifitas Penggunaan Formaldehid Sebagai Pelindung Protein Terhadap Kecernaan InVitro Protein Kasar Bungkil Kelapa. Seminar Nasional Teknologi Peternakan

Amritama, D. 2007. Asap Cair. http://tech.groups.yahoo.comessage/ 7945. Diakses tanggal 17 maret 2015
Erwanto, 1995. Optimalisasi Sistem Fermentasi Rumen Melalui Suplementasi Sulfur, Defaunasi, Reduksi Emisi Metan dan Stimulasi Pertumbuhan Mikrobia pada Ternak Ruminansia. Tesis. Program Pasca Sarjana Institut Pertanian Bogor.

Ferguson, K.A 1975. The Protection of Dietary Proteins and Amino Acids Against Microbial Fermentation in the Rumen. In McDONALD, L.W. and A.C.I WARNER. Digestion and Metabolism in the Ruminant, 448464, Ed. University of the New England Publishing Unit Armidale.

Hernaman, I. 2009. Penggunaan Crude Palm Oil Sebagai Agen Proteksi Metionin Melawan Degradasi Mikroba Rumen. Fakultas Peternakan Universitas Padjadjaran. Bandung.

Harris,H., Dandy E., dan Ikromatun. N. 2012. Potensi Pengembangan Industri Tepung Ikan Dari Limbah Pengolahan Makanan Tradisional Khas Palembang Berbasis Ikan. Jurnal Pembangunan Manusia Vol.6 No.2

Hugate, R.E. 1966. The Rumen and Its Microbes, Avademic Press, Inc. Hal 8-330.

Instalansi Penelitian dan Pengkajian Teknologi Pertanian. 1996. Pakan Ayam Buras. DKI Jakarta.

Gusasi, A. 2014. Nilai pH, Produksi Gas, Konsentrasi Amonia dan VFA Rumen In Vitro Ransum Berbahan Jerami Padi, Daun Gamal dan Urea Mineral Molases Liquid. Fakultas Peternakan. Universitas Hasanudin Makasar.

Nishimuta, J.F, D. G. Ely and J.A Boling. 1973. Nitrogen Metabolism in Lambs Fed Soybean Meal Treated with Heat, Formalin and Tannic Acid. J. Nutr.103:49-53. 
Purwati. 2018

Parakkasi, A. 1999 Ilmu Nutrisi dan Makanan Ternak Ruminan. Universitas Indonesia Press, Jakarta.

Purwati, C. S. 2010. "Pengaruh penggunaan minyak ikan lemuru, minyak kelapa sawit, dan bungkil sawit terproteksi terhadap kecernaan bahan kering, bahan organik, protein, $\mathrm{pH}$ dan $\mathrm{NH}_{3}$ cairan rumen sapi PO berfistula". Skripsi. Universitas Sebelas Maret. Surakarta.

Soeparno. 2005. Ilmu dan Teknologi Daging.Gadjah Mada University Press, Yogyakarta.

Soebarinoto, S. Chuzaemi, dan Mashudi. 1991. IImu Gizi Ruminansia. Universitas Brawijaya. Malang.
Tilley, 1M.A .. and R.A. Terry. 1967. A two stage technique foe in the in-vitro digestion of forage crops. J. Grassland Soc.18: 104.

Wibowo, U. 2006. Pengaruh Pemberian FormalinTerhadap Aktifitas Enzim Tripsin Pada Feses Sapi Melalui Uji Gelatin. Skripsi. Fakultas Kedokteran Hewan, Institut Pertanian Bogor.

Yitnosumarto, S. 1993. Perancangan Percobaan Analisis dan Interprestasinya. Gramedia Pustaka Utama, Yogyakarta.

Yunus, M 2011: Teknologi Pembuatan Asap Cair dari Tempurung Kepala Sebagai Pengawet Makanan. Jurnal Sains dan Inovasi 7(1) 53-61 